\title{
Kajian Tentang Pengembangan Eggurt dengan Fortifkasi Edamame sebagai Agen Antioksidan
}

\section{The Study on the Development of Eggurt with the Fortification of Edamame as an Antioxidant Agent}

\author{
D. Triasih* dan D. A. Priyadi \\ ${ }^{1}$ Program Studi Teknologi Pengolahan Hasil Ternak, Politeknik Negeri Banyuwangi \\ JL. Raya Jember-Banyuwangi KM 13, Banyuwangi, 68461 - Indonesia \\ *Corresponding E-mail: triasihdyah@gmail.com
}

(Diterima: 11 September 2020; Disetujui: 26 Maret 2021)

\begin{abstract}
ABSTRAK
Penelitian ini bertujuan untuk mengetahui pengaruh penambahan sari edamame terhadap kualitas kualitas kimia ( $\mathrm{pH}$, kadar air, kadar abu, kadar protein, dan kadar lemak) serta aktivitas antioksidan pada eggurt. Penambahan edamame pada eggurt dimaksudkan untuk meningkatkan kandungan kimia serta aktivitas antioksidan karena sari edamame mengandung flavonoid dan fenol yang tinggi. Pembuatan eggurt dengan memfermentasi susu murni dan putih telur menggunakan bakteri BAL berupa Lactabacillus bulgaricus dan Streptococcus thermophilus kemudian diinkubasi pada suhu $42^{\circ} \mathrm{C}$ sampai membentuk curd atau nilai $\mathrm{pH}$ mencapai 4,5. Eggurt dibuat dengan menambahkan sari edamame sesuai dengan perlakuan. Perlakuan yang digunakan yaitu P1 (sari edamame 5\%), P2 (sari edamame 10\%), P3 (sari edamame 15\%), dan P4 (sari edamame 20\%). Selanjutnya data dianalisis menggunakan analisis varian (ANOVA). Apabila terdapat beda nyata, maka dilanjutkan dengan uji Duncan dengan taraf $1 \%$. Hasil penelitian menunjukkan penambahan edamame berpengaruh sangat nyata $(\mathrm{P}<0,01)$ terhadap kadar air, kadar abu, kadar protein, dan kadar lemak eggurt, dan aktivitas antioksidan sedangkan tidak berpengaruh nyata $(\mathrm{P}>0.05)$ terhadap parameter $\mathrm{pH}$ pada eggurt. Hasil penelitian dapat disimpulkan bahwa penambahan sari edamame pada eggurt dengan kosentrasi $20 \%$ berpengaruh dengan meningkatkan nilai kadar air, kadar protein, kadar lemak, dan antioksidan, serta menurunkan nilai kadar abu, namun tidak berpengaruh terhadap nilai $\mathrm{pH}$.
\end{abstract}

Kata Kunci: eggurt, edamame, kualitas kimia, antioksidan

\section{ABSTRACT}

This study aims to determine the effect of adding edamame juice on chemical quality ( $\mathrm{pH}$, moisture content, ash content, protein content, and fat content) and the antioxidant activity of eggurt. Edamame to eggurt is intended to increase chemical content and antioxidant activity because edamame juice contains high flavonoids and phenols. Making eggurt by fermenting pure milk and egg white using LAB bacteria in the form of Lactobacillus bulgaricus and Streptococcus thermophilus then incubated at a temperature of $42^{\circ} \mathrm{C}$ to form a curd or a $\mathrm{pH}$ value of 4.5. Eggurt is made by adding edamame juice according to treatment. The treatments used were P1 (5\% edamame extract), P2 (10\% edamame extract), P3 (15\% edamame extract), and P4 (20\% edamame extract). Furthermore, the data were analyzed using analysis of variance (ANOVA). If there is a significant difference, then proceed with the Duncan test with a level of $1 \%$. The results showed that the addition of edamame had a very significant effect $(P<0.01)$ on water content, ash content, protein content and eggurt fat content, and antioxidant activity. In contrast, it had no significant effect $(P>0.05)$ on $\mathrm{pH}$ parameters in eggurt. The results showed that the addition of edamame juice to eggurt with a concentration of $20 \%$ affected increasing the value of water content, protein content, fat content, and antioxidants, as well as decreasing the value of the ash content. Still, it did not affect the $p H$ value.

Keywords: eggurt, edamame, chemical quality, antioxidant 


\section{PENDAHULUAN}

Susu adalah jenis bahan pangan fungsional yang memiliki kandungan gizi yang lengkap. Kandungan gizi yang cukup tinggi pada susu menjadi salah satu potensi Penyebab perkembangan mikroba dapat mengakibatkan susu mudah mengalami kerusakan baik secara fisik maupun kimia. Faktor yang dapat menyebabkan kerusakan pada susu, antara lain faktor fisik, faktor kimia, dan mikrobiologi. Namun yang menjadi faktor utama dalam kerusakan susu adalah faktor mikrobiologi. Kerusakan secara mikrobiologi disebabkan karena susu mudah terkontaminasi oleh mikroba. Susu dapat mengalami kontaminasi pada proses pemerahan sampai dengan pengolahan. Hal ini akan mengakibatkan masa simpan susu yang berkurang dengan menggunakan suhu ruang (Hariyadi, 2000). Salah satu cara untuk mencegah kerusakan adalah dengan cara fermentasi susu. Fermentasi pada susu bertujuan untuk memperpanjang daya simpan susu. Oleh karena itu diperlukan salah satu teknologi pengolahan susu yaitu pembuatan eggurt.

Eggurt adalah salah satu jenis minuman fungsional yang bahan dasar berasal dari susu segar dan putih telur yang telah difermentasi menggunakan bakter asam laktat yaitu Streptococcus thermophillus dan Lactobacillus bulgaricus (Stadelman et al., 1990). Putih telur yang ditambahkan pada pembuatan eggurt bertujuan meningkatkan viabilitas bakteri. Hal ini disebabkan kandungan yang tinggi pada putih telur sehingga dapat meningkatkan cita rasa, tekstur, dan nilai gizi. Menurut penelitian Indratiningsih et al. (2011), bahwa eggurt dengan perlakuan wijen memiliki kualitas sensori dan mikrobiologi paling tinggi dibandingkan, namun kualitas paling tinggi adalah eggurt dengan perlakuan kedelai hitam. Penambahan jenis kedelai dalam produk fermentasi susu mampu meningkatkan nilai gizi dan memperbaiki rasa serta tekstur pada eggurt.

Dalam penelitian ini penambahan edamame berfungsi meningkatkan nilai gizi, terutama protein karena edamame merupakan sumber protein tinggi serta sebagai sumber antikoksidan. Kandungan protein mencapai $36 \%$ daripada jenis kedelai lainnya. Kandungan lain dari edamame yaitu 9 asam amino esensial, kaya serat, vitamin C dan $\mathrm{B}$, tidak mengandung kolesterol, lemak jenuh, kalsium, zat besi, magnesium, dan asam folat. Menurut penelitian Samruan et al. (2012), bahwa kedelai edamame mengandung komponen fitokimia yaitu isoflavon $(0,1-$ $3 \%)$, sterol $(0,23-0,46 \%)$, dan saponin $(0,12-$ $6,16 \%$ ) yang mampu berfungsi sebagai agen antioksidan.

Tujuan dari penelitian ini yaitu untuk mengetahui pengaruh penambahan edamame dalam produk eggurt terhadap kualitas kimia $(\mathrm{pH}$, kadar air, kadar protein, kadar lemak, dan kadar abu) serta aktivitas antioksidan sehingga didapatkan produk minuman fungsional yang baik untuk kesehatan. Konsumsi eggurt edamame diharapkan mampu meningkatkan imunitas dalam tubuh dan menangkal radikal bebas.

\section{METODE}

Penelitian ini menggunakan peralatan seperti pisau, timbangan, oven, vortex, hotplate, gelas beaker, pipet ukur, $\mathrm{pH}$ meter, sentrifuge, tabung reaksi, mikropipet, spektrofotometer, cawan petri, jarum ose, dan inkubator. Bahan yang digunakan dalam penelitian ini meliputi: susu sapi, putih telur, isolat Lactobacillus bulgaricus dan Streptococcus thermophillus, edamame dan bahan-bahan yang diperlukan untuk analisa $\mathrm{K}_{2} \mathrm{SO}_{4}, \mathrm{HgO}, \mathrm{H}_{2} \mathrm{SO}_{4}$ pekat, $\mathrm{NaOH} 60 \%, \mathrm{HCl}$, heksan, asam borat, dan indikator MB:MM, buffer $\mathrm{pH} 7.0$ dan 4.0, akuades, $\mathrm{NaOH}$, asam oksalat, asam tannat, reagen Folin-Dennis, $\mathrm{Na}_{2} \mathrm{CO}_{3}, \mathrm{MRSA}, \mathrm{NaCl}$, kertas Whatman no.1, alkohol $70 \%$, dan indikator PP.

Prosedur penelitian pada tahap pertama adalah persiapan pembuatan eggurt dengan melakukan proses fermentasi susu sapi segar 
dan ditambahkan $10 \%$ putih telur ayam (albumin), setelah itu dilakukan penambahan $5 \%$ bakteri Lactobacillus bulgaricus dan Streptococcus diinkubasi dengan suhu $42^{\circ} \mathrm{C}$ dengan menggunakan perbandingan 1:1 sampai membentuk gumpalan (curd) dengan $\mathrm{pH} 4$,5. Sebelum mengalami proses fermentasi menggunakan bakteri BAL, bahan dasar yaitu susu dan albumin telah mengalami proses pasteurisasi dengan tujuan untuk membunuh bakteri pathogen. Pasteurisasi menggunakan suhu $75-90^{\circ} \mathrm{C}$ selama 15 detik atau HTST, sedangkan untuk albumin dipasteurisasi dengan suhu $50^{\circ} \mathrm{C}$ selama 15 detik, sedangkan putih telur di pasteurisasi pada suhu $50^{\circ} \mathrm{C}$ selama 15 detik untuk menginaktifkan zat antibakteri dalam putih telur. Tahap kedua penambahan edamame dalam eggurt. Sebelum ditambahkan, edamame direbus dengan suhu $80^{\circ} \mathrm{C}$ selama 15 menit kemudian diblender sehingga didapatkan sari edamame yang dicampurkan kedalam eggurt. Edamame ditambahkan dengan konsentrasi penambahan $5 \%, 10 \%, 15 \%$, dan $20 \%$. Setelah eggurt dan edamame dicampur dilakukan uji kimia $(\mathrm{pH}$, kadar protein, kadar abu kadar air, serta kadar lemak) dan aktivitas antioksidan. Analisis sifat kimia meliputi analisis nilai $\mathrm{pH}$ menggunakan $\mathrm{pH}$ meter, analisis kadar air menggunakan metode berat konstan, analisis kadar abu menggunakan metode furnace, analisis kadar protein menggunakan metode kjeldahl, analisis kadar lemak menggunakan metode soxhlet, serta aktivitas antioksidan menggunakan metode DPPH.

Analisa data penelitian ini menggunakan Rancangan Acak Lengkap (RAL) dengan pola searah dengan perlakuan konsentrasi sari edamame yang berbeda yaitu $5 \%, 10 \%, 15 \%$, dan $20 \%$ kemudian masing-masing sampel diulangi sebanyak 3 kali ulangan sehingga total ada 12 sampel. Data hasil analisis diolah menggunakan ANOVA dengan taraf signifikansi $5 \%$. Apabila terdapat perbedaan yang nyata maka akan dilanjutkan dengan uji lanjut Duncan.

\section{HASIL DAN PEMBAHASAN}

Hasil uji lanjut pH, kadar protein, kadar abu kadar air, serta kadar lemak) dan aktivitas antioksidan eggurt dengan fortifikasi sari edamame metode DMRT (Duncan's Multiple Range Test) menunjukkan pengaruh yang sangat nyata $(\mathrm{P}<0,01)$ namun nilai $\mathrm{pH}$ menunjukkan pengaruh yang tidak nyata $(\mathrm{P}>0,05)$ (Tabel 1).

\section{Nilai pH}

Hasil analisis ragam menunjukkan bahwa penambahan sari edamame berpengaruh tidak berpengaruh nyata $(\mathrm{P}>0,05)$ terhadap $\mathrm{pH}$ eggurt. Nilai $\mathrm{pH}$ yang didapatkan yaitu kisaran 4,5-4,9 dengan waktu fermentasi selama 24 jam. Nilai $\mathrm{pH}$ eggurt mengalami penurunan seiring dengan peningkatan konsentrasi sari edamame. Dalam proses fermentasi, bakteri Lactobacillus bulgaricus dan Streptococcus akan menghasilkan asam laktat. Pada tahap fermentasi akan terjadi proses hidrolisis dari sari edamame yang ditambahkan pada eggurt, karena produk ini tinggi akan kandungan protein. Tingginya kandungan protein yang terhidrolisis mengakibatkan $\mathrm{pH}$ mengalami penurunan, hal ini disebabkan reaksi enzim protease mampu dalam memecah ikatan peptide sehingga mengakibatkan lepasnya gugus karboksilat dan pembebasan sejumlah ion hidrogen (Anggraini, 2015). Faktor yang mempengaruhi protein, selain itu penurunan nilai $\mathrm{pH}$ karena lamanya proses fermentasi. Semakin lama terjadinya proses fermentasi akan berdampak peningkatan jumlah asam laktat yang diproduksi, maka asam laktat semakin tinggi dan $\mathrm{pH}$ akan semakin turun (Rosiana, 2016). Streptococcus thermophilus berfungsi dalam penurunan nilai $\mathrm{pH}$ serta proses sintesis asam format dalam pertumbuhan bakteri Lactobacillus bulgaricus, apabila terjadi proses penurunan pH sampai 4 mengakibatkan Lactobacillus bulgaricus akan membebaskan asm amino seperti histidine, valin, serta glisin yang dibutuhkan dalam perkembangan dan memiliki fungsi memberikan aroma dan flavor (Winarno, 2002). Penurunan $\mathrm{pH}$ 
Tabel 1. Hasil pengujian kimia eggurt dengan penambahan edamame

\begin{tabular}{lcccc}
\hline \multirow{2}{*}{ Parameter } & \multicolumn{4}{c}{ Perlakuan } \\
\cline { 2 - 5 } & P1 & P2 & P3 & P4 \\
\hline pH & 4.7 & 4,6 & 4,5 & 4,5 \\
Kadar air (\%) & $81,4^{\mathrm{a}}$ & $81,9^{\mathrm{b}}$ & $82,5^{\mathrm{c}}$ & $83,1^{\mathrm{d}}$ \\
Kadar abu (\%) & $0,95^{\mathrm{a}}$ & $0,91^{\mathrm{b}}$ & $0,88^{\mathrm{c}}$ & $0,83^{\mathrm{d}}$ \\
Kadar protein (\%) & $4,39^{\mathrm{a}}$ & $4,51^{\mathrm{b}}$ & $4,74^{\mathrm{c}}$ & $4,89^{\mathrm{d}}$ \\
Kadar lemak (\%) & $0,58^{\mathrm{a}}$ & $0,64^{\mathrm{b}}$ & $0,69^{\mathrm{c}}$ & $0,72^{\mathrm{d}}$ \\
Antioksidan (\%) & $16,9^{\mathrm{a}}$ & $18,07^{\mathrm{b}}$ & $19,3^{\mathrm{c}}$ & $20,9^{\mathrm{d}}$ \\
\hline
\end{tabular}

juga dipengaruhi oleh kadar glukosa dalam media. Bakteri L. Bulgaricus dan bakteri S. Thermophillus mampu memfermentasi glukosa menjadi asam laktat dengan cepat, sehingga mengakibatkan semakin turunnya aktivitas bakteri yang dibuktikan dengan semakin berkurangnya jumlah BAL yang masih hidup (Mulyani et al., 2008).

\section{Kadar Air}

Hasil analisis ragam menunjukkan bahwapenambahan sariedamame berpengaruh sangat nyata $(\mathrm{P}>0,01)$ terhadap eggurt. Kadar air pada eggurt berada pada kisaran $81,4 \%$ $83,1 \%$, adanya perbedaan kandungan kadar air eggurt ini dikarenakan kosentrasi sari edamame yang semakin tinggi maka akan menggakibatkan kadar air dalam eggurt tinggi. Kadar air akan mempengaruhi tingkat viskositas eggurt. Penambahan sari edamame dengan kosentrasi 20\% menghasilkan kadar air $83.1 \%$ dibandingkan dengan penambahan sari edamame 5\% menghasilkan kadar air $81,4 \%$, hal ini karena semakin tinggi kosentrasi penambahan sari edamame mengakibatkan semakin meningkat kadar air eggurt. Eggurt dengan kadar air yang tinggi menghasilkan tekstur yang encer karena rendahnya nilai viskositas, menurunnya viskositas disebabkan karena semakin besar jumlah kadar air bebas (Air berfungsi sebagai pengemulsi dari proses fermentasi. Emulsi yang dihasilkan dalam proses berupa emulsi minyak dan air $(\mathrm{O} / \mathrm{W})$, yaitu minyak sebagai fase terdispersi dan air sebagai fase kontinyu (Nuraeni et al., 2019). Tinggi rendahnya kadar air dalam suatu bahan pangan tergantung akan proses pengolahan dan fermentasi (Khadafihatul dan Fatchiyah, 2014). Sesuai penelitian Agustina dan Andriana (2010), bahwa kadar air yoghurt susu kacang hijau sekitar 84,98\% sampai $85,12 \%$, hal ini disebabkan sejumlah air yang ditambahkan dan lama proses pemanasan pada saat sterilisasi (Triyon et al., 2009).

\section{Kadar Abu}

Hasil analisis ragam menunjukkan bahwa penambahan sari edamame berpengaruh sangat nyata $(\mathrm{P}<0,01)$ terhadap eggurt. Kadar abu eggurt edamame berkisar antara $0,83 \% \quad-\quad 0,95 \%$. Lama proses fermentasi akan meningkatkan kandungan mineral eggurt, dalam proses fermentasi terjadi perubahan glukosa menjadi asam laktat serta dapat menghasilkan jenis mineral tertentu yaitu magnesium. Semakin banyak glukosa yang terfermentasi menjadi asam laktat maka akan semakin banyak mineral yang dihasilkan (Harjiyanti, 2012). Bahan baku yang digunakan untuk menyusun suatu produk akan mempengaruhi tinggi rendahnya kandungan mineral (Permata et al., 2016). Susu sapi mengandung mineral seperti kalsium, magnesium, dan fosfor. Menurut Askar (2005), bahwa Semakin tingginya kadar abu, mengakibatkan semakin tinggi kandungan mineral.

\section{Kadar Protein}

Hasil analisis ragam menunjukkan bahwa penambahan sari edamame berpengaruh sangat nyata $(\mathrm{P}<0,01)$ terhadap eggurt. Kadar protein tertinggi pada $\mathrm{P} 4$ dengan 
penambahan ekstrak edamame sebesar $20 \%$ yaitu 4,89\%. Penambahan edamame pada eggurt akan meningkatkan protein eggurt. Tinggi rendahnya kadar protein pada eggurt tergantung pada bahan baku yang digunakan dan akan berpengaruh pada tingkat tekstur dari eggurt. Hal ini sesuai dengan penelitian Chairunnisa et al. (2010), total dari nilai kadar protein produk berhubungan dengan total kadar protein bahan baku yang digunakan. Kandungan protein mempengaruhi jumlah bakteri BAL (Streptococcus thermophilus dan Lactobacillus bulgaricus). Sumber nitrogen dan karbon digunakan BAL untuk berkembang dan tumbuh. Sehingga jumlah mikroba semakin banyak dalam eggurt, akibatnya semakin tinggi kadar proteinya sebab sebagian besar komponen penyusun bakteri yaitu protein (Yusmarini dan Effendi, 2004). BAL berperan dalam peningkatan enzim yang berfungsi memecah protein menjadi peptide dan akan dihidrolisis menjadi asam amino (Setioningsih et al., 2004).

\section{Kadar Lemak}

Hasil analisis ragam menunjukkan bahwapenambahan sariedamame berpengaruh sangat nyata $(\mathrm{P}<0,01)$ terhadap eggurt. Kadar lemak tertinggi pada P4 yaitu 0,72\%, dengan pengaruh penambahan sari edamame sebesar 20\% sedangkan kadar lemak terendah pada P1 yaitu $0,58 \%$, dengan pengaruh penambahan sari edamame 5\%. Semakin tinggi kosentrasi penambahan sari edamame mengakibatkan semakin meningkatkan kadar lemak pada eggurt. Hal ini dikarenakan aktivitas enzim lipase BAL cenderung lemah jika bahan pangan yang ditambahkan adalah lemak rantai panjang. Komposisi utama edamame adalah asam linoleat atau yang disebut dengan asam lemak omega 6. BAL mengalami kesulitan dalam memecah ikata lemak sehingga tidak dapat terhidrolisis dan mengakibatkan peningkatkan kadar lemak pada eggurt. Selain itu tinggi rendahnya kadar lemak yang ada dalam eggurt ditentukan oleh prosentase bahan dasar yang digunakan. Berdasarkan hasil penelitian didapatkan kadar lemak dengan penambahanan sari edamame sekitar $0,58 \%-0,72 \%$. Sedangkan menurut penelitian Sukiran et al. (2019), bahwa kadar lemak susu edamame sekitar $5,74 \%$, selama proses fermentasi berlangsung lemak akan mengalami hidrolisis menjadi senyawa yang lebih sederhana. Proses hidrolisis trigliserida oleh enzim lipase akan menghasilkan asam lemak dan gliserol (Serlahwaty, 2015). Menurut Michal (2010), bahwa bakteri asam laktat akan menghasilkan enzim lipase mengakibatkan lemak akan terhidrolisis dan terjadi penurunan kadar lemak, selain itu terjadinya penurunan kadar lemak juga diakibatkan dari bakteri BAL menggunakan lemak sebagai sumber energi serta pembentukan flavor (Nofrianti, 2013). Semakin meningkat jumlah BAL maka kebutuhan akan lemak semakin meningkat karena nutrisi yang dibutuhkan juga semakin meningkat (Gardiner, 2000).

\section{Antioksidan}

Berdasarkan uji anova menunjukkan penambahan edamame berpengaruh sangat nyata $(\mathrm{P}<0,01)$ terhadap aktivitas antioksidan eggurt. Aktivitas antioksidan pada eggurt mengalami peningkatan yang signifikan pada perlakuan edamame dengan kosentrasi $20 \%$, hal ini karena edamame mengandung senyawa fenol dan isoflavon yang merupakan jenis antioksidan, dalam metobolit eggurt akan menghasilkan peptide biokatif yang memiliki sifat antioksidan. Hal ini sesuai dengan penelitian Kartikasari dan fithri (2014), bahwa semakin lama proses fermentasi maka akan meningkatkan hasil metabolit dan menghasilkan total fenolik yang tinggi sehingga akan semakin tinggi aktivitas antioksidannya. Faktor yang menyebabkan terjadinya peningkatan antioksidan yaitu peningkatan kadar asam laktat serta penurunan nilai pH (Af'idah, 2019). Asam laktat, asam asetat, asam sitrat, asam suksinat, asam malat, asetaldehid, diasetil, dan asetoin adalah senyawa yang dapat meningkatkan aktivitas antioksidan dan berfungsi sebagai penstabil dalam fermentasi, dengan cara bersinergi dalam proses meregenarasi senyawa antioksidan. 


\section{KESIMPULAN}

Kesimpulan yang dapat diambil berdasarkan hasil penelitian yang telah dilakukan adalah penambahan sari edamame pada eggurt dengan kosentrasi 20\% berpengaruh dengan meningkatkan nilai kadar air, kadar protein, kadar lemak, dan antioksidan, serta menurunkan nilai kadar abu, namun tidak berpengaruh terhadap nilai $\mathrm{pH}$.

\section{DAFTAR PUSTAKA}

Af'idah, F. dan G. Trimulyono. 2019. Uji aktivitas antioksidan dan kadar asam laktat yoghurt tempe kedelai (Glycine $\max$ ) dan yoghurt tempe kacang hijau (Vigna radiata). Lentera Bio. 8(1): 1724.

Amrun, H.M., Umiyah, dan Evi Umayah, U. 2007. Uji Aktifitas Antioksidan Ektrak Air dan Ektrak Metanol Beberapa Varian Buah Kenitu (Chrysophyllum cainito L) dari daerah Jember, Berk, Penel. Hayati. 13: 45-50.

Anggraini, A. dan Yunianta. 2015. Pengaruh suhu dan lama hidrolisis enzim papain terhadap sifat fisik, kimia, dan organoleptik sari edamame. Jurnal Pangan Dan Agroindustri. 3(3):10151025.

Askar, Surayah, dan Sugiarto. 2005. Uji kimiawi dan organoleptik sebagai uji mutu yoghurt. Prosiding Temu Teknis Nasional Tenaga Fungsional Pertanian. Bogor: Balai Besar Penelitian Pasca Panen Pertanian.

Chairunnisa, H., W.S. Putranto, dan S.J. Lepa. 2010. Karakteristik produk fermentasi dari bahan baku kombinasi susu kambing dengan ekstrak kedelai, ekstrak jagung, atau santan kelapa. Jurnal Teknologi dan Industri Pangan. 12(1): 91-94.

Gardiner, G.E., O, Sulivan., J. Kelly, A.E. Auty, G.F. Fitgerald, J.K. Collins, R.P. Ross, and C. Stanton. 2000. Comparative Survival Rates Of Human Derived Probioticlactobacillus Paracasei And Lactobacillus Salivarius. New York: American Society for Microbiology.

Hariyadi, P. 2004. Dasar dasar Teori dan Praktek Proses Termal. Pusat Studi Pangan dan Gizi IPB, Bogor.

Harjiyanti, M. D., Y.B. Pramono, dan S. Mulyani. 2012. Total asam, viskositas, dan kesukaan pada yogurt drink dengan sari buah mangga (Mangifera indica) sebagai perisa alami. Jurnal Aplikasi Teknologi Pangan. 2(2): 104-107.

Indratiningsih, R. Nurliyani, W. Endang, dan H. Widodo. 2011. Kualitas eggurt kering dengan bahan dasar susu dan berbagai macam biji-bijian. Buletin Peternakan. 35(2): $107-112$.

Kartikasari D.I., dan C.N. Fithri. 2014. Pengaruh penambahan sari buah sirsak dan lama fermentasi terhadap karakteristik fisik dan kimia yoghurt. Jurnal Pangan dan Agroindustri 2(4): 239-248.

Khadafihotul, L. dan Fatchiyah. 2014. Karakter biokimia dan profil protein yogurt kambing pe difermentasi bakteri karakter biokimia dan profil protein yogurt kambing PE difermentasi Bakteri Asam Laktat (BAL). J.Exp. Life Sci. 3(1):1-6.

Michal, I.U. 2010. Pengaruh kosentrasi starter Lactobacillus bulgaricus dan Streptococcus thermophillus terhadap kualitas yoghurt susu kambing. Skripsi. Universitas Negeri Maulana Malik Ibrahim. Malang.

Mulyani, S., A. M. Legowo, dan A. A. Mahanani. 2008. Viabilitas bakteri asam laktat, keasaman dan waktu pelelehan es krim probiotik menggunakan starter Lactobacillus casei dan Bifidobacterium bifidum. J. Indon. Trop. Anim. Agric. 33 (2) : 120- 125.

Nofrianti, R., F. Azima, dan R. Eliyasmi. 2013. Pengaruh penambahan madu terhadap 
mutu yoghurt jagung. Jurnal Aplikasi Teknologi Pangan. 2(2):61-67.

Nuraeni, S.,R. Purwasih, R. dan A. Romalasari. 2019. Analisa proksimat yoghurt susu kambing dengan penambahan jeruk bali (Citrus grandis L.Osbeck).Jurnal Ilmiah Ilmu dan Teknologi Rekayasa. 2(1):20-24 .

Permata, D.A., H. Ikhwan, dan Aisman. 2016. Aktivitas proteolitik papain kasar getah buah papaya dengan berbagai metode pengeringan. J. Teknologi Pertanian Andalas. 20(2): 58 - 64 .

Rosiana, M.N., dan D.I. Amareta. 2016. Karakteristik yoghurt edamame hasil fermentasi kultur campuran bakteri asam laktat komersial sebagai pangan fungsional berbasis biji-bijian. Seminar Hasil Penelitian dan Pengabdian Masyarakat Dana BOPTN. ISBN. 978602-14917-3-7.

Samruan, W., R. Oonsivilai, and A. Oonsivilai. 2012. Soybean and Fermented Soybean Extract Antioxidant Activity. World Academy of Science, Engineering and Technology, Suranaree University of Technology, Thailand,

Serlahwaty, D., Syarmalina, dan N. Sari. 2015. Analisis kandungan lemak dan protein terhadap kualitas soygghurt dengan penambahan susu skim. Berkala Ilmiah Kimia Farmasi. 4(2): 35-42.

Setioningsih, E., R. Setyaningsih, dan A. Susilowati. 2004. Pembuatan minuman probiotik dari susu kedelai dengan inokulum Lactobacillus casei, Lactobacillus plantarum, dan Lactobacillus acidophilus. Jurnal Bioteknologi. 1(1): 1-6.

Stadelman, W.J., M.Olson, G.A.Shemwel, and S.Pasch. 1990, Egg and Poultry Meat-Processing. VCH. Publishing Inc, USA.

Sukiran, N.M., H. Santoso, dan A. Syauqi. 2019. Analisis lemak susu olahan biji edamame (Glycin max L. var edamame) fat milk analysis of processed edamame bean (Glycin max L. var edamame). Jurnal Sains Alami. 2(1):32-36.

Triyono, A. T. Rahman, W. Agustina, dan N. Rahman, 2009, Peningkatan fungsi dan keanekaragaman produk olahan kacang hijau (Phaseolus radiatus L.) menjadi susu nabati dn produk turunannya. Laporan Akhir Program DIKTI. Subang: B2PTTG-LIPI.

Winarno, F.G. 2002. Kimia Pangan Dan Gizi. Jakarta: PT. Gramedia Pustaka Utama.

Winarsi, H., A.T. Septiana, Kartini, dan I.N. Hanifah. 2019. Fermentasi bakteriasam-laktat meningkatkan kandungan fenolik dan serat yogurt susu kecambah kacang merah (Phaseolus vulgaris L.), minuman fungsional untuk obesitas. J,Gipas. 3(1): $64-75$.

Yusmarini dan Effendi. 2004. Evaluasi mutu soygurt yang dibuat dengan penambahan beberapa jenis gula. Jurnal Indonesia 6(2): 104-110. 